\title{
Studies on $\left[{ }^{3} \mathrm{H}\right]$ palmitate-binding proteins of rat spermatozoa: a post-translational modification of membrane proteins by fatty acid acylation
}

\author{
A. Srivastava* and G. E. Olson \\ Cell Biology, Vanderbilt University, Nashoille, TN 37232, USA
}

\begin{abstract}
The purpose of the present study was to demonstrate the post-translational modifications of sperm plasma membrane proteins by fatty acid acylation during sperm maturation in the epididymis. Rat epididymal spermatozoa were incubated at $37^{\circ} \mathrm{C}$ with various concentrations $(100 \mu \mathrm{Ci}$ and $\mathrm{I} \mathrm{mCi})$ of $\left[9-10(n)^{3} \mathrm{H}\right]$ palmitic acid in a medium containing Tyrode's solution supplemented with sodium bicarbonate, sodium pyruvate and sodium lactate. The incorporation of $\left[{ }^{3} \mathrm{H}\right]$ palmitate in vitro was determined in epididymal spermatozoa and an attempt was made to identify the lipid-linked proteins of purified plasma membranes of maturing epididymal spermatozoa by autoradiography. The studies demonstrated that $\left[{ }^{3} \mathrm{H}\right]$ palmitate was covalently linked to a subset of membrane cytoskeleton proteins of maturing rat spermatozoa. The pattern of incorporation of lipid was a maturation-associated phenomenon as caput spermatozoa incorporated more radioactivity than did caudal spermatozoa. The labelled proteins appeared to be membrane-bound since $82 \%$ of radioactivity was associated with membrane fractions. Autoradiograms of SDS-PAGE gels of labelled caput sperm extract showed three prominent palmitate-incorporating protein bands of about 70,56 and $36 \mathrm{kDa}$ and few minor bands. Most of these proteins were present in the membrane fraction of caput spermatozoa. Labelled gels of both the sperm extracts and of purified membranes showed resistance to hydroxylamine treatment, suggesting that there are amide bonds between lipid and proteins. The higher incorporation of labelled palmitate by immature spermatozoa of the caput epididymis compared with mature spermatozoa from the cauda epididymis and the addition of palmitate to plasma membrane proteins of caput epididymal spermatozoa suggest that fatty acylation is a post-translational modification of sperm membrane proteins.
\end{abstract}

\section{Introduction}

Mammalian spermatozoa cannot fertilize eggs upon leaving the testis, but gradually acquire this ability as they pass through the epididymis. This sperm maturation process includes various morphological, physiological and biochemical changes on the sperm surface (for reviews see Eddy, 1988; Yanagimachi, 1988). Although the structure and function of mammalian spermatozoa have been the subject of intensive study during recent years and there have been numerous reports on the presence and distribution of several cytoskeletal proteins in the mammalian spermatozoa (Primakoff et al., 1987; Lakoski et al., 1989; Camatini et al., 1991; Srivastava and Olson, 1991), how the membrane-associated protein modifications contribute to the maturation of spermatozoa remains largely unresolved. A variety of membrane proteins of cellular and viral origin are modified by covalent attachment of long-chain fatty acids (for reviews see Magee and Schlesinger, 1982; Schultz et al., 1988;

*Present address: Division of Endocrinology, Central Drug Research Institute, Post Box Number 173, Lucknow - 226001, India.

Received 9 February 1996.
James and Olson, 1990). Several intracellular proteins are acylated by myristate, a process that appears to take place cotranslationally for a variety of soluble and membrane proteins (Carr et al., 1982; Schultz and Oroszlan, 1984; Buss and Sefton, 1985). In contrast, several proteins are acylated by palmitate, a post-translational event that occurs exclusively on membrane proteins, as reported for the transferrin receptor (Omary and Trowbridge, 1981) and the membrane cytoskeleton protein, ankyrin (Staufenbiel and Lazarides, 1986).

The plasma membrane of maturing spermatozoa plays a significant role in the preparation of spermatozoa for fertilization. The phospholipid composition of the plasma membrane as well as the phospholipid distribution in the membrane leaflets are of particular importance for the process of capacitation and fusion (Hinkovska et al., 1986; Hinkovska-Galcheva and Srivastava, 1993). There have been numerous reports on the lipid content of whole spermatozoa from a variety of species (Parks et al., 1987; Lin et al., 1993) and there is a decrease in the amount of sperm lipid during transit through the epididymis in several species (Nikolopoulou et al., 1985; Parks and Hammerstedt, 1985). In addition, alterations in sperm 
membrane lipids have been noted during capacitation and acrosome reaction of spermatozoa (Lee et al., 1986; Wolf et al., 1986). However, very little is known about the fatty acid acylated proteins of the membrane cytoskeleton of mammalian spermatozoa. The purpose of the present study was to identify the post-translationally modified, fatty acylated proteins of sperm membrane during epididymal sperm maturation in rats.

\section{Materials and Methods}

\section{Materials}

[9-10 $\left.(n)^{3} \mathrm{H}\right]$ palmitic acid was obtained from Amersham (Searle, Arlington Heights, IL); acrylamide, bis-acrylamide, sodium dodecyl sulfate (SDS), hydroxylamine hydrochloride and other chemicals for electrophoresis were from Fisher Scientific Company (Norcross, GA). Tyrode's salts, leupeptine, pepstatin and benzamidine hydrochloride were purchased from Sigma Chemical Company (St Louis, MO). For radioactive counting, Ready Solve TM Scintillation Cocktail was purchased from Beckman (Palo Alto, CA). The Kodak X-OMAT C films for autoradiography were obtained from Eastman Kodak Company (Rochester, NY).

\section{Animals}

Adult male Sprague-Dawley rats were anaesthetized with sodium pentobarbital (Nembutal; Abbott Laboratories, North Chicago, IL) (30 mg per $0.5 \mathrm{ml}$ saline, i.p.) and were perfused retrograde via the spermatic artery to clear the epididymis of blood with Tyrode's solution containing $12 \mathrm{mmol}$ sodium bicarbonate $1^{-1}, 1.0 \mathrm{mmol}$ sodium pyruvate $\mathrm{I}^{-1}$ and $9.0 \mathrm{mmol}$ sodium lactate $1^{-1}(\mathrm{pH} 7.6)$. The epididymides were removed and the caput and cauda epididymides were dissected out.

\section{Sperm preparation and labelling conditions}

Epididymal segments were minced with a razor blade and the spermatozoa released were collected with a Pasteur pipette. An aliquot of the spermatozoa was taken for counting using a haemocytometer under a phase-contrast microscope and for protein estimation by the method of Bradford (1976). The sperm cells were washed three times with Tyrode's solution and were incubated with $\left[9-10(n)^{3} \mathrm{H}\right]$ palmitic acid (specific activity $30 \mathrm{Ci} \mathrm{mmol}^{-1}$ ) at a concentration of $100 \mu \mathrm{Ci}$ for $\mathrm{I} \mathrm{h}$ at $37^{\circ} \mathrm{C}$ in Tyrode's solution containing $1 \mathrm{mg} \mathrm{BSA} \mathrm{ml}{ }^{-1}$. To study the effect of time on incorporation of $\left[{ }^{3} \mathrm{H}\right]$ palmitate, the incubation period was varied from $30 \mathrm{~min}$ to $2 \mathrm{~h}$ at $100 \mu \mathrm{Ci}$ $\left[{ }^{3} \mathrm{H}\right]$ palmitate. For observation of appreciable amounts of radiolabelled proteins in autoradiography, the spermatozoa were incubated with $1 \mathrm{mCi}\left[{ }^{3} \mathrm{H}\right]$ palmitate for $2 \mathrm{~h}$ at $37^{\circ} \mathrm{C}$.

\section{Preparation of sperm extract}

At the end of the incubation, the spermatozoa were washed three times in Tyrode's solution and were pelleted by centrifugation at $500 \mathrm{~g}$ for $10 \mathrm{~min}$. The resultant supernatant was freeze-dried and reconstituted in Laemmli sample buffer for electrophoresis. The pellets were boiled in Laemmli sample buffer $\left(0.125 \mathrm{~mol}\right.$ Tris- $\mathrm{HCl} \mathrm{I} \mathrm{I}^{-1}, \mathrm{pH} 6.8,4 \%(\mathrm{w} / \mathrm{v})$ sodium dodecyl sulphate (SDS), 20\% (v/v) glycerol, $10 \%(\mathrm{v} / \mathrm{v})$ $\beta$-mercaptoethanol and $0.1 \%(\mathrm{w} / \mathrm{v})$ bromophenol blue) and were centrifuged at $8000 \mathrm{~g}$ for $5 \mathrm{~min}$ in an Eppendorf centrifuge (Model 5415). The supernatant consisting of sperm extract was desalted on a PDIO column (Pharmacia Inc., Piscataway, NJ), freeze-dried and reconstituted in Laemmli sample buffer for determination of amount of radioactivity and SDS-PAGE analysis.

\section{Determination of radioactivity}

Radioactivity was determined by incubating $25 \mu$ labelled sperm extracts with $10 \%(\mathrm{w} / \mathrm{v})$ trichloroacetic acid (TCA) and BSA ( $1 \mathrm{mg} \mathrm{ml}^{-1}$ ) for $15 \mathrm{~min}$ at $4^{\circ} \mathrm{C}$. The TCA precipitates were collected on Millipore filters $(0.45 \mu \mathrm{m}$ pore size) and were washed four times each with $10 \%(w / v)$ TCA and then by chloroform:methanol $(2: 1)$. The filters were dried and dissolved in methyl cellosolve. Radioactivity was determined in a Beckman Counter Model LS 3801 using a Beckman Ready Solve TM scintillation cocktail.

\section{Membrane isolation}

The incorporation of radiolabelled palmitate was examined in purified plasma membranes of spermatozoa to demonstrate that lipid-containing proteins were membrane bound. The spermatozoa were labelled with $\left[{ }^{3} \mathrm{H}\right]$ palmitate at $1.0 \mathrm{mCi}$ for $2 \mathrm{~h}$ at $37^{\circ} \mathrm{C}$ in Tyrode's solution containing BSA as described above. The sperm pellets obtained after washing with Tyrode's solution were resuspended in TNI buffer $(25 \mathrm{mmol}$ Tris- $\mathrm{HCl}$ $1^{-1} \mathrm{pH} 7.5,150 \mathrm{mmol}$ sodium chloride $\mathrm{I}^{-1}, 2.5 \mathrm{mmol}$ benzamidine $\mathrm{I}^{-1}, 1 \mu \mathrm{g}$ leupeptin $\mathrm{ml}^{-1}, 1 \mu \mathrm{g}$ pepstatin $\mathrm{ml}^{-1}$ and $0.05 \%(\mathrm{w} / \mathrm{v})$ sodium azide) for membrane isolation. The purified plasma membranes were obtained as described by Srivastava and Olson (1991) with minor modifications. Briefly, labelled spermatozoa were disrupted by nitrogen cavitation at $4^{\circ} \mathrm{C}$ at a pressure of $2760 \mathrm{kPa}$ and an equilibration period of $10 \mathrm{~min}$. The cavitated spermatozoa were then centrifuged for $15 \mathrm{~min}$ at $500 \mathrm{~g}$ to pellet the spermatozoa (pellet 1). Aliquots of the supernatant fluid were centrifuged at $100000 \mathrm{~g}$ for $1.5 \mathrm{~h}$ in a Beckman SW-41 rotor to collect the released membranes. The resultant pellet was reconstituted in TNI buffer and centrifuged at $100000 \mathrm{~g}$ for $1 \mathrm{~h}$ in a Beckman 100.3 ultracentrifuge. The membrane pellets obtained were resuspended in TNI buffer and were used for determination of radioactivity and SDS-PAGE analysis. The supernatant (cytosol) was desalted on a PD10 column, freeze-dried and was reconstituted in Laemmli sample buffer for further counting and SDS-PAGE.

\section{Polyacrylamide gel electrophoresis (SDS-PAGE) and autoradiography}

SDS-PAGE was performed according to the method of Laemmli (1970). The sperm pellet, supernatant and plasma membranes were solubilized in Laemmli sample buffer. The proteins were fractionated on $1.5 \mathrm{~mm}$ thick, $10-15 \%$ gradient polyacrylamide gels for $3.5 \mathrm{~h}$ at $15 \mathrm{~W}$ per gel with cooling to 
Table 1. Incorporation of $\left[{ }^{3} \mathrm{H}\right]$ palmitate $\left(100 \mu \mathrm{Ci}\right.$ for $\mathrm{Ih}$ at $\left.37^{\circ} \mathrm{C}\right)$ by maturing spermatozoa from the rat epididymis

\begin{tabular}{|c|c|c|c|c|}
\hline $\begin{array}{l}\text { Spermatozoa } \\
(n)\end{array}$ & $\begin{array}{l}\text { c.p.m. } 10^{-7} \\
\text { spermatozoa } \\
\text { (mean } \pm \text { SEM) }\end{array}$ & $\begin{array}{c}\text { Percentage } \\
\text { incorporation }^{a}\end{array}$ & $\begin{array}{c}\text { c.p.m. } \mu^{-1} \\
\text { protein } \\
(\text { mean } \pm \mathrm{SEM})\end{array}$ & $\begin{array}{c}\text { Percentage } \\
\text { incorporation }\end{array}$ \\
\hline $\begin{array}{l}\text { Washed caput } \\
\text { (7) }\end{array}$ & $\begin{array}{l}478327.2 \\
\pm 85373.6\end{array}$ & 94.1 & $\begin{array}{r}1586.8 \\
\pm 283.5\end{array}$ & 85.6 \\
\hline $\begin{array}{l}\text { Washed caudal } \\
\text { (7) }\end{array}$ & $\begin{array}{l}29960.6 \\
\pm 3404.0\end{array}$ & 5.9 & $\begin{array}{r}267.3 \\
\pm 30.7\end{array}$ & 14.4 \\
\hline $\begin{array}{l}\text { Unwashed caput } \\
\text { (3) }\end{array}$ & $\begin{array}{l}404380.3 \\
\pm 14213.2\end{array}$ & 95.0 & $\begin{array}{r}1341.1 \\
\pm 471.4\end{array}$ & 87.6 \\
\hline $\begin{array}{l}\text { Unwashed caudal } \\
\text { (3) }\end{array}$ & $\begin{array}{l}21085.8 \\
\pm 4557.0\end{array}$ & 5.0 & $\begin{array}{r}189.0 \\
\pm 40.8\end{array}$ & 12.4 \\
\hline
\end{tabular}

\footnotetext{
${ }^{a}$ The percentage incorporation of radioactivity by caput and caudal spermatozoa was calculated with the total sum of c.p.m. of two segments considered to be $100 \%$. number of observations.
}

$4^{\circ} \mathrm{C}$. After electrophoresis the gels were fixed in $50 \%$ methanol for $30 \mathrm{~min}$. One set of gels was treated with 1 mol hydroxylamine $\mathrm{I}^{-1}$ ( $\mathrm{pH} 8.0$ ) for $2 \mathrm{~h}$ to test for ester-linked fatty acids. The dried gels were treated with amplify solution (Amersham) for $30 \mathrm{~min}$ and dried in a gel drier at $67^{\circ} \mathrm{C}$ for $1 \mathrm{~h}$. The dried gels were put for fluorography (Bonner and Laskey, 1974) at $-70^{\circ} \mathrm{C}$ for 50 days using Kodak X-OMAT C film. In a separate set of gels, the proteins were visualized by the silver staining method of Wray et al. (1981).

\section{Results}

Incorporation of $\left[^{3} H\right]$ palmitate by maturing spermatozoa

Spermatozoa from both caput and cauda epididymides were incubated with $\left[9-1 \mathrm{O}(n)^{3} \mathrm{H}\right]$ palmitate at various concentrations and for various periods to investigate whether proteins of the sperm membrane cytoskeleton incorporate long chain fatty acids during epididymal sperm maturation. Preliminary experiments performed with $\left[{ }^{3} \mathrm{H}\right.$ lpalmitate $(100 \mu \mathrm{Ci})$ in incubation medium for $1 \mathrm{~h}$ indicated that immature spermatozoa from the caput epididymis incorporated more radioactivity than did mature spermatozoa from the cauda epididymis. The pattern of incorporation did not change when incorporation was expressed as c.p.m. $10^{-7}$ spermatozoa (caput spermatozoa $94.1 \%$; caudal spermatozoa $5.9 \%$ ) or as c.p.m. $\mu \mathrm{g}^{-1}$ protein (caput spermatozoa $85.6 \%$; caudal spermatozoa $14.4 \%$ ). Slightly more incorporation of radioactivity was observed in spermatozoa washed repeatedly with Tyrode's solution before incubation than in unwashed spermatozoa. This finding suggests that some epididymal fluid proteins attached to the sperm surface may compete for the palmitate label (Table 1). The caput spermatozoa continued to show higher incorporation of radioactivity, even when the incubation time was varied from $30 \mathrm{~min}$ to $2 \mathrm{~h}$ or the concentration of tritiated palmitate was raised to $1.0 \mathrm{mCi}$ in the incubation medium (Fig. 1). This pattern of incorporation was maintained when radioactivity was extracted with TCA, was washed repeatedly with chloroform:methanol and radioactivity was expressed as c.p.m. $\mu \mathrm{g}^{-1}$ protein (Fig. 2), suggesting that radioactivity was specifically and tightly bound to the sperm surface proteins.

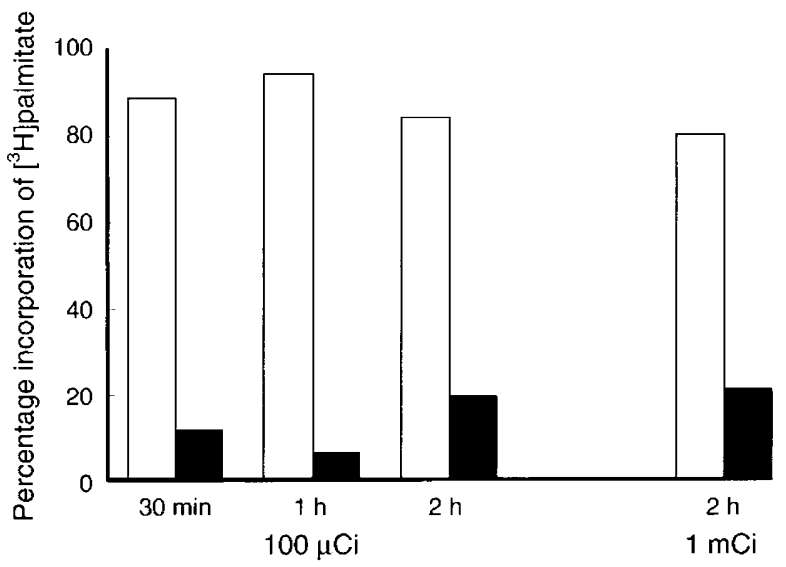

Fig. 1. Percentage incorporation of $\left[{ }^{3} \mathrm{H}\right]$ palmitate by maturing rat spermatozoa (incorporation of $\left[{ }^{3} \mathrm{H}\right]$ palmitate measured in c.p.m. $10^{-7}$ spermatozoa). Epididymal spermatozoa were incubated with $100 \mu \mathrm{Ci}$ labelled palmitate for $30 \mathrm{~min}, \mathrm{I} \mathrm{h}$ and $2 \mathrm{~h}$ and with $1.0 \mathrm{mCi}$ for $2 \mathrm{~h}$ at $37^{\circ} \mathrm{C}$. The percentage incorporation of radioactivity by caput $(\square)$ and caudal (ם) spermatozoa was calculated with the total c.p.m. of the two segments considered to be $100 \%$.

Spermatozoa from the caput epididymis seemed to incorporate less palmitate when incubated for a longer period $(2 \mathrm{~h})$ at both $100 \mu \mathrm{Ci}$ and $1 \mathrm{mCi}$ of radiolabelled palmitate, as compared with incorporation after $\mathrm{I} h$ incubation. However, caudal spermatozoa showed slightly higher incorporation at $2 \mathrm{~h}$ than at $1 \mathrm{~h}$ duration (Figs 1 and 2).

\section{Analysis of acyl proteins by SDS-PAGE}

Autoradiograms of SDS-PAGE gel of labelled caput sperm extract showed three prominent palmitate-incorporating bands of about 70, 56 and $36 \mathrm{kDa}$, and few minor bands of about 92 , $48,31,29,22$ and $19 \mathrm{kDa}$ (Fig. 3). Detection of these bands required prolonged fluorographic exposure (50 days) of the gel to duplicating film even though $1.0 \mathrm{mCi}$ of tritiated palmitate was used, raising the possibility that only a small fraction of sperm proteins is modified by the addition of lipid and palmitate is incorporated into proteins to a very small degree. 


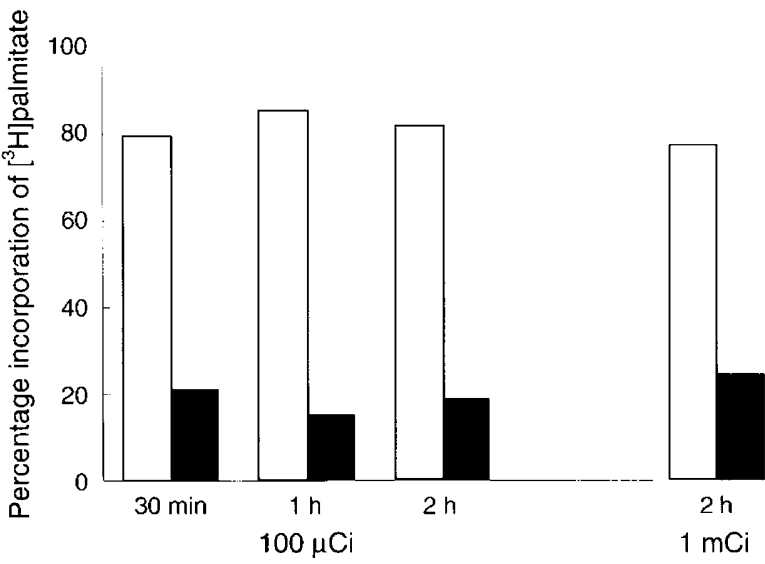

Fig. 2. Percentage incorporation of $\left[{ }^{3} \mathrm{H}\right]$ palmitate by maturing rat spermatozoa (incorporation of $\left[{ }^{3} \mathrm{H}\right]$ palmitate measured in c.p.m. $\mu \mathrm{g}^{-1}$ protein). Epididymal spermatozoa were incubated with $100 \mu \mathrm{Ci}$ labelled palmitate for $30 \mathrm{~min}, 1 \mathrm{~h}$ and $2 \mathrm{~h}$ and with $1.0 \mathrm{mCi}$ for $2 \mathrm{~h}$ at $37^{\circ} \mathrm{C}$. The percentage incorporation of radioactivity by caput $(\square)$ and caudal ( $\boldsymbol{\square}$ ) spermatozoa was calculated with the total c.p.m. of the two segments considered to be $100 \%$.

\section{Membrane bound acyl proteins}

Caput spermatozoa were labelled with $1.0 \mathrm{mCi}$ of palmitate for $2 \mathrm{~h}$ and purified plasma membrane fractions were obtained to investigate whether these proteins were associated with plasma membranes. Radioactivity was measured in different subcellular fractions: the sperm pellet (the pellet obtained after releasing membrane supernatant by nitrogen cavitation and centrifugation), the membrane pellet (the pellet obtained after ultracentrifugation of membrane supernatant at $100000 \mathrm{~g}$ ) and cytosol (the supernatant obtained after pelleting membrane vesicles). An examination of the pattern of incorporation in different subcellular fractions suggested that the majority of the $\left[^{3} \mathrm{H}\right]$ palmitate binding proteins were membrane-bound since $82 \%$ of radioactivity (c.p.m. $\mu \mathrm{g}^{-1}$ protein) was recovered in the membrane pellet as compared with $13.0 \%$ in the sperm pellet and $5.0 \%$ in the cytosol fractions (Fig. 4). Autoradiograms of SDS-PAGE gels of purified plasma membranes from labelled caput spermatozoa revealed two prominent bands of about 70 and $36 \mathrm{kDa}$, and four minor bands of about $31,29,22$ and $19 \mathrm{kDa}$, similar bands to those produced by the caput sperm extracts. However, two proteins of 92 and $56 \mathrm{kDa}$ present on caput sperm extract were not observed in the autoradiogram of membrane fraction (Fig. 5). Figure 6 shows the silver-stained gel of the sperm pellet, supernatant and membrane pellet of spermatozoa from the caput epididymis.

\section{Chemical nature of lipid linkage to sperm cells}

The association of sperm membrane proteins with tritiated palmitate appeared to consist of tight, covalent interactions between fatty acid and proteins. The covalent nature of this association was suggested by the fact that the lipid attachment was stable even after repeated extractions of labelled TCAprecipitated proteins with (I) chloroform:methanol (2:I), (2) boiling the extracted proteins with $4 \%(\mathrm{w} / \mathrm{v})$ SDS and $10 \%(\mathrm{v} / \mathrm{v}) \beta$-mercaptoethanol and (3) SDS gel electrophoresis.

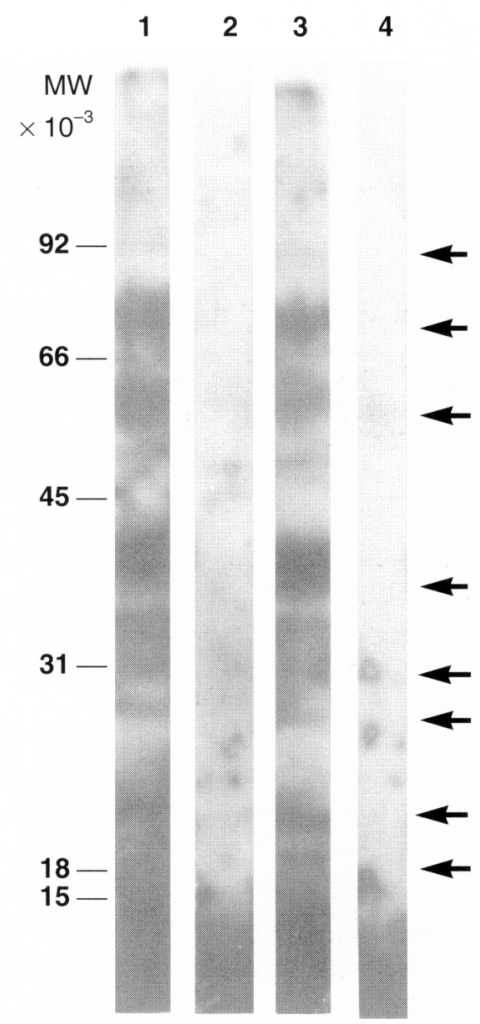

Fig. 3. Autoradiograms of SDS-PAGE gel of caput rat spermatozoa labelled with $1.0 \mathrm{mCi}$ of $\left[{ }^{3} \mathrm{H}\right]$ palmitate for $2 \mathrm{~h}$ at $37^{\circ} \mathrm{C}$. The radioactivity was extracted with $10 \%(\mathrm{w} / \mathrm{v})$ trichloroacetic acid containing BSA ( $1 \mathrm{mg} \mathrm{ml}{ }^{-1}$ ) and then repeated washings with chloroform: methanol $(2: 1)$. The fluorograms were kept for 50 days at $-70^{\circ} \mathrm{C}$ using Kodak X-OMAT C film. Lane 1, caput sperm extract; lane 2, caput sperm supernatant (gel without hydroxylamine treatment). Lanes 3 and 4, caput sperm extract and supernatant (gel treated with $1.0 \mathrm{~mol}$ hydroxylamine $1^{-1}, \mathrm{pH} 8.0$, for $2 \mathrm{~h}$ ). Arrows show the palmitylated proteins. Molecular mass (MW) markers are indicated on the left.

One set of gels containing $\left[{ }^{3} \mathrm{H}\right]$ palmitate-labelled sperm proteins was treated with $1 \mathrm{~mol}$ hydroxylamine $\mathrm{l}^{-1}$ ( $\mathrm{pH} 8.0$ ), for $2 \mathrm{~h}$ to test the chemical stability of the linkage between the label and the protein. This treatment did not release the radioactive label on gels of labelled sperm extracts (Fig. 3, lanes 2 and 4) or on gels of purified sperm plasma membrane (Fig. 5, lane 2). These observations suggest that fatty acids are linked covalently to sperm membranes through tight amide bonds.

\section{Discussion}

The data presented here support the hypothesis that fatty acid acylation of membrane proteins is a post-translational modification in rat sperm cells, based on the observation that, in other cell systems, acylation of proteins with palmitate is a posttranslational phenomenon. In the present study, palmitic acid labelled a subset of proteins in sperm cells and the label was specifically and tightly bound to sperm surface proteins as evidenced by extraction of radioactivity with TCA and repeated washings with chloroform:methanol (2:1). Most of the 


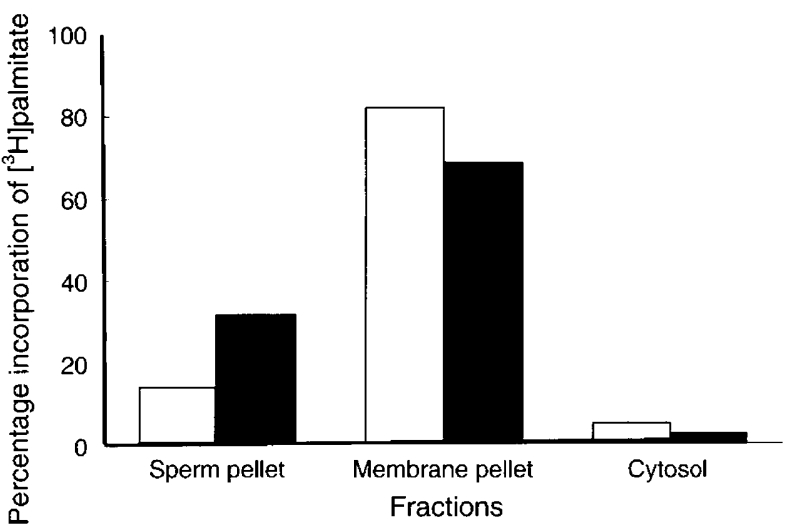

Fig. 4. Distribution of radioactivity of $\left[{ }^{3} \mathrm{H}\right]$ palmitate in subcellular fractions of rat caput ( $\square$ ) and caudal ( $\mathbf{\square}$ ) spermatozoa. The percentage incorporation was calculated on the basis of total c.p.m. of all the fractions considered to be $100 \%$.

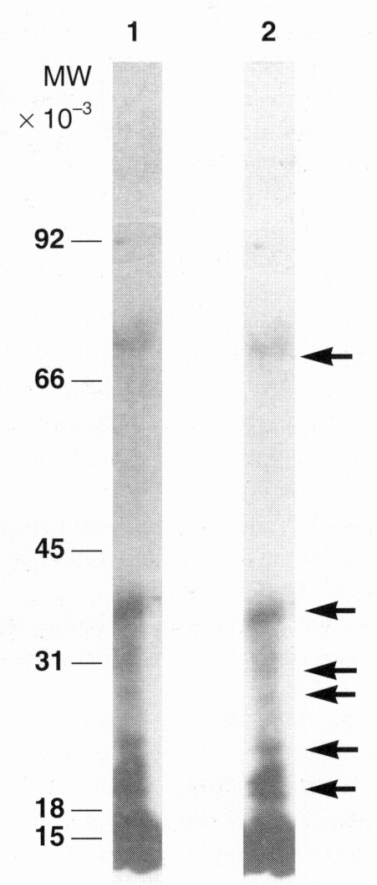

Fig. 5. Autoradiogram of SDS-PAGE gel containing purified plasma membrane of rat caput spermatozoa treated with $1.0 \mathrm{mCi}$ of $\left[{ }^{3} \mathrm{H}\right]$ palmitate for $2 \mathrm{~h}$. Lane 1 , caput sperm membrane without hydroxylamine treatment; lane 2, caput sperm membrane with hydroxylamine treatment (1.0 mol $\mathrm{l}^{-1}, \mathrm{pH} 8.0$ ) for $2 \mathrm{~h}$.

labelled proteins fractionated with the plasma membrane, as would be expected for proteins modified with a hydrophobic acyl chain. The fatty acid in sperm cells did not appear to be covalently linked by ester bonds, as it was insensitive to hydrolysis with hydroxylamine. However, it was found to be linked via amide bonds, as described for the $\alpha$-subunit of the insulin receptor (Hedo et al., 1987), Escherichia coli lipoprotein (Hantke and Braun, 1973), bovine cardiac muscle cAMPdependent protein kinase (Carr et al., 1982), murine leukaemia membrane associated proteins P15 and pp60 src (Sefton et al., 1982; Henderson et al, 1983) and the $\alpha$ - and $\beta$-subunits of the nicotinic acetylcholine receptor (Olson et al., 1984).

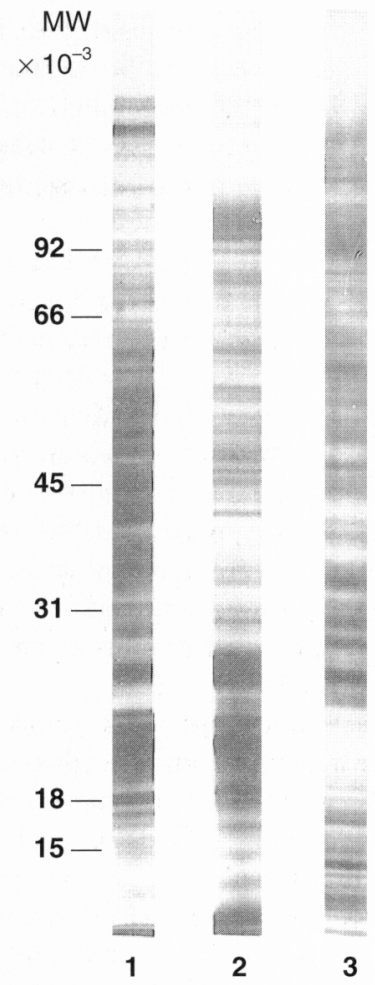

Fig. 6. Silver-stained gel containing rat caput sperm pellet (lane 1), supernatant (lane 2) and purified plasma membrane (lane 3). Molecular mass $(\mathrm{MW})$ markers are indicated on the left.

In initial experiments, the incubation of sperm cells with labelled palmitate $(100 \mu \mathrm{Ci})$ for a period of $I \mathrm{~h}$ showed a high incorporation of radioactivity associated with TCA extracts of caput spermatozoa, but exhibited only faint bands on fluorographs after exposure for 20 days. Hence, both the concentration of palmitate in the incubation medium and the period of incubation were increased $(1.0 \mathrm{mCi}$ for $2 \mathrm{~h}$ ) in subsequent experiments. The incubation of spermatozoa with $1 \mathrm{mCi}$ palmitic acid for $2 \mathrm{~h}$ and the prolonged fluorographic exposures of the gel for 50 days resulted in more appreciable protein bands on the fluorograms but raised the possibility that palmitate is incorporated into sperm proteins to a lower degree, with only a small fraction of sperm proteins specifically modified by the addition of lipid.

In the present study, the incorporation of tritiated palmitate in sperm cells appeared to be a maturation-associated phenomenon, as evidenced by the higher incorporation of labelled lipids by immature caput spermatozoa than by mature caudal spermatozoa. The pattern of incorporation of palmitate by maturing sperm cells may be related to decreased amounts of lipid during transport through the epididymis or could be due to barriers to palmitate uptake in caudal spermatozoa. A decrease in the amount of sperm lipid during transit through the epididymis has been ascribed to the utilization of lipids by spermatozoa as energy sources and would explain the greater sensitivity of ejaculated spermatozoa to cold shock and the decreased membrane fluidity of spermatozoa during maturation of epididymal spermatozoa (Vijayasarathi and Balram, 1982; Nikolopoulou et al., 1985). The variation in fluidity may regulate specific functions of sperm membranes associated with 
capacitation and membrane fusion at the time of acrosome reaction (Hinkovska-Galcheva and Srivastava, 1993).

In the present study, the possibility of incorporation of radioactivity by plasmalogens of cytoplasmic droplets or caput spermatozoa can be ruled out, as the combination of tritiated palmitate with plasmalogens would produce ester bonds and not amide bonds. These two types of bond can be differentiated by hydroxylamine sensitivity experiments.

The identification of a long chain fatty acid AMP-dependent coenzyme A sulphydryl ligase (CoASH(AMP)), in human spermatozoa is consistent with the ability of spermatozoa to metabolize palmitic acid. CoASH ligase localized in the plasma membrane, the mitochondria or both, could be involved in energy production, motility or membrane remodelling (Jones et al., 1985). The reduced uptake of tritiated palmitate by caput spermatozoa after incubation for $2 \mathrm{~h}$ as compared with I h could be due to hydrolysis of labelled palmitate by $\mathrm{CoASH}$ ligase in caput spermatozoa.

The highly specific localization of palmitylated proteins in sperm plasma membrane represents a minor fraction of cellular components. This raises intriguing questions about the intracellular pathways followed by acylated proteins and about the role of fatty acylation in sperm cells. Palmitylation of integral membrane proteins in other cell systems may influence protein-protein interaction and protein-lipid interactions within membranes by affecting protein folding or protein orientation (Schlesinger and Malfer, 1982; Olson et al., 1984; Olson and Spizz, 1986). The post-translational addition of lipids may, therefore, be the means by which these proteins acquire affinity for membranes (Olson and Spizz, 1986), or may provide a mechanism for routing nonglycosylated proteins to the cytoplasmic face of the plasma membrane (Wilcox and Olson, 1987). Another role for fatty acids in acylated proteins is to anchor the proteins in the lipid bilayer by providing an additional hydrophobic moiety (Marinetti and Cattieu, 1982; Magee and Schlesinger, 1982; Schmidt, 1983). The fatty acid acylated proteins also play a significant role as components of intracellular signalling pathways (James and Olson, 1990) and may be involved in fusion induction similar to viral membrane glycoproteins (Schmidt, 1983).

It is premature to comment on the role of acylated proteins in membrane-associated changes in spermatozoa during the complex process of maturation. Further studies are needed to establish their role in inducing membrane fusion processes during capacitation and acrosome reaction of spermatozoa and as components of intracellular signalling pathways during fertilization.

The authors thank V. P. Kamboj, Director, CDRI for taking interest in the study and S. Ray for critical comments. The authors also thank the World Health Organization, Geneva for financial support (Research Training Grant to A. Srivastava).

\section{References}

Bonner WM and Laskey RA (1974) A film detection method for tritium labeled proteins and nucleic acids in polyacrylamide gels European Journal of Biochemistry 46 83-88

Bradford MM (1976) A rapid and sensitive method for the quantitation of microgram quantities of protein utilizing the principle of protein-dye binding Analytical Biochemistry 72 248-254
Buss JE and Sefton BM (1985) Myristic acid, a rare fatty acid, is the lipid attached to the transforming protein of Rous sarcoma virus and its cellular homolog Journal of Virology $\mathbf{5 3} 7-12$

Camatini M, Colombo A and Bonfanti P (1991) Identification of spectrin and calmodulin in rabbit spermiogenesis and spermatozoa Molecular Reproduction and Development 28 62-69

Carr SA, Biemann K, Shoji S, Parmelee DC and Titani K (1982) n-Tetradecanoyl is the $\mathrm{NH}_{2}$-terminal blocking group of the catalytic subunit of cyclic AMP-dependent protein kinase from bovine cardiac muscle Proceedings of the National Academy of Sciences USA 79 6128-6131

Eddy EM (1988) The spermatozoon. In The Physiology of Reproduction Vol. I pp 27-68 Eds E Knobil and JD Neil. Raven Press Ltd, New York

Hantke K and Braun V (1973) Covalent binding of lipid to protein. Diglyceride and amide-linked fatty acid at the $\mathrm{N}$-terminal end of the murein-lipoprotein of the Escherichia coli outer membrane European Journal of Biochemistry 34 284-296

Hedo JA, Collier E and Watkinson A (1987) Myristyl and palmityl acylation of the insulin receptor Journal of Biological Chemistry 262 954-957

Henderson LE, Krutzsch HC and Oroszlan S (1983) Myristyl amino terminal acylation of murine retrovirus proteins: an unusual post-translational protein modification Proceedings of the National Academy of Sciences USA $\mathbf{8 0}$ 339-343

Hinkovska VT, Dimitrov GP and Koumanov KS (1986) Phospholipid composition and phospholipid asymmetry of ram spermatozoa plasma membranes International Journal of Biochemistry 18 1115-1121

Hinkovska-Galcheva V and Srivastava PN (1993) Phospholipids of rabbit and bull sperm membranes: structural order parameter and steady state fluorescence anistropy of membranes and membrane leaflets Molecular Reproduction and Development 35 209-217

James G and Olson EN (1990) Fatty acylated proteins as components of intracellular signalling pathways Biochemistry $29 \quad 2622-2634$

Jones RE, Plymate SR and Fariss BL (1985) Activation of palmitic acid by human spermatozoa Journal of Andrology 6 265-270

Laemmli UK (1970) Cleavage of structural proteins during the assembly of the head of the bacteriophage T4 Nature 227 680-685

Lakoski K, Williams C and Saling P (1989) Proteins of the acrosomal region in mouse sperm: immunological probes reveal post-testicular modifications Gamete Research $2321-37$

Lee CN, Handrow RR, Lenz RW and Ax RL (1986) Interactions of seminal plasma and glycosaminoglycans on acrosome reaction in bovine spermatozoa in vitro Gamete Research 12 345-356

Lin DS, Connor WE, Wolf DP, Neuringer M and Hachey DL (1993) Unique lipids of primate spermatozoa: desmosterol and docosahexaenoic acid Journal of Lipid Research 34 491-499

Magee AI and Schlesinger MJ (1982) Fatty acid acylation of eucaryotic cell membrane proteins Biochimica et Biophysica Acta 694 279-289

Marinetti GA and Cattieu K (1982) Tightly (covalently) bound fatty acids in cell membrane proteins Biochimica et Biophysica Acta $685109-116$

Nikolopoulou M, Soucek DA and Vary JC (1985) Changes in the lipid content of boar sperm plasma membranes during epididymal maturation Biochimica et Biophysica Acta 815 486-498

Olson EN and Spizz G (1986) Fatty acylation of cellular proteins. Temporal and subcellular differences between palmitate and myristate acylation Journal of Biological Chemistry $2612458-2466$

Olson EN, Glaser L and Merlie JP (1984) Alpha and beta subunits of the nicotinic acetylcholine receptor contain covalently bound lipid journal of Biological Chemistry 259 5364-5367

Omary MB and Trowbridge IS (1981) Biosynthesis of the human transferrin receptor in cultured cells Journal of Biological Chemistry $25612888-12892$

Parks JE and Hammerstedt RH (1985) Developmental changes occurring in the lipids of ram epididymal spermatozoa plasma membrane Biology of Reproduction 32 653-668

Parks JE, Arizon JW and Foote RH (1987) Lipids of plasma membrane and outer acrosomal membrane from bovine spermatozoa Biology of Reproduction 37 $1249-1258$

Primakoff P, Hyatt $\mathbf{H}$ and Tredick-Kline $\mathbf{H}$ (1987) Identification and purification of a sperm surface protein with a potential role in sperm-egg membrane fusion Journal of Cell Biology 104 141-149

Schlesinger MJ and Malfer C (1982) Blocking fatty acid acylation of glycoproteins inhibits vesicular stomatitis and Sindbus virus particle formation Journal of Biological Chemistry $2579887-9890$ 
Schmidt MF (1983) Fatty acid binding: a new kind of post-translational modification on membrane proteins Current Topics in Microbiology and Immunology 102 101-129

Schultz A and Oroszlan S (1984) Myristylation of gag-onc fusion proteins in mammalian transforming retroviruses Virology 133 431-437

Schultz AM, Henderson LE and Oroszlan S (1988) Fatty acylation of proteins Annual Review of Cell Biology 4 611-647

Sefton BM, Trowbridge IS, Cooper JA and Scolnick EM (1982) The transforming proteins of Rous sarcoma virus, Harvey sarcoma virus and Abelson virus contain tightly bound lipid Cell $31465-474$

Srivastava A and Olson GE (1991) Glycoprotein changes in the rat sperm plasma membrane during maturation in the epididymis Molecular Reproduction and Development 29 357-364

Staufenbiel M and Lazarides E (1986) Ankyrin is fatty acid acylated in erythrocytes Proceedings of the National Academy of Sciences USA 83 318-322
Vijayasarathi S and Balram P (1982) Regional differentiation in bull sperm plasma membranes Biochemical and Biophysical Research Communications 108 760-764

Wilcox CA and Olson EN (1987) The majority of cellular fatty acid acylated proteins are localized to the cytoplasmic surface of the plasma membrane Biochemistry 26 1029-1036

Wolf DE, Hagopian SS and Ishijima I (1986) Changes in sperm plasma membrane lipid diffusibility after hyperactivation during in vitro capacitation in the mouse Journal of Cell Biology 102 1372-1377

Wray W, Boulikas T, Wray VP and Handcock RP (1981) Silver staining of proteins in polyacrylamide gels Analytical Biochemistry 118 197m 203

Yanagimachi R (1988) Mammalian fertilization. In The Physiology of Reproduction Vol. 1 pp 135-185 Eds E Knobil and ID Neil. Raven Press Ltd, New York 